\title{
Changing preferences for information and participation in the last phase of life: a longitudinal study
}

among newly diagnosed advanced lung cancer patients.

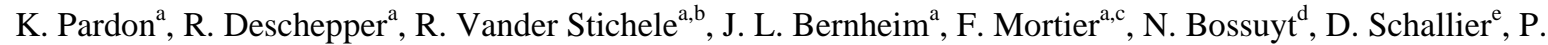
Germonpré $^{\mathrm{f}}$, D. Galdermans ${ }^{\mathrm{g}}$, W. Van Kerckhoven ${ }^{\mathrm{h}}$, L. Deliens ${ }^{\mathrm{a}, \mathrm{i}}$, on behalf of the EOLIC-consortium ${ }^{l}$

${ }^{a}$ End-of-Life Care Research Group, Ghent University \& Vrije Universiteit Brussel, Brussels, Belgium

${ }^{\mathrm{b}}$ Heymans Institute for Pharmacology, Ghent University, Ghent, Belgium

${ }^{c}$ Bioethics Institute Ghent, Ghent University, Ghent, Belgium

${ }^{\mathrm{d}}$ Scientific Institute of Public Health, Department of Epidemiology, Brussels, Belgium

${ }^{\mathrm{e}}$ Department of Medical Oncology, University Hospital of Brussels, Brussels, Belgium

${ }^{\mathrm{f}}$ Department of Pulmonary Medicine, Antwerp University Hospital, Edegem, Belgium

${ }^{\mathrm{g}}$ Department of Pulmonary Medicine, ZNA Middelheim Hospital, Antwerp, Belgium

${ }^{\mathrm{h}}$ Department of Pulmonary Medicine, Hospital Sint-Augustinus, Wilrijk, Belgium

${ }^{\mathrm{i}}$ Department of Public and Occupational Health, EMGO Institute for Health and Care Research, VU University Medical Centre, Amsterdam, the Netherlands

Correspondence to:

Koen Pardon, End-of-life Care Research Group Ghent University \& Vrije Universiteit Brussel

Vrije Universiteit Brussel

Laarbeeklaan 103, 1090 Brussels, Belgium

Tel: ++32475.50 .25 .05$

koen.pardon@vub.ac.be

l This EOLIC study on End-Of-Life Information and Communication was conducted in collaboration with a consortium of physicians who all recruited advanced lung cancer patients for inclusion in this study:, Dirk Ommeslag, Roger Devogelaere, Jan Van Meerbeeck, Jan Lamont, Anneke Lefebure, Lut Van Moorter, Elinck Willy, Annelies Janssens, Emmanuel Potvin, Alix Debrock, Dirk Verresen, Els De Droogh, Christophe Pollefliet, Karim Vermaelen and Elke van Schoote. 


\section{Abstract}

Purpose: Objective is to explore changes over time in the information and participation preferences of newly diagnosed stage IIIb/IV non-small-cell lung cancer patients.

Methods: Patients were recruited by physicians in 13 hospitals and interviewed every two months until the fourth and every four months until the sixth interview.

Results: Sixty seven patients were interviewed 3 times. Over a period of four months from diagnosis, half of patients changed their information preferences for palliative care and end-of-life decisions with a possible or certain life-shortening effect (ELDs, e.g. non-treatment decisions) in both directions, from not wanting to wanting the information, but also - and as much - from wanting to no longer wanting it. The latter were more likely to be in a better physical condition. Preferences for participation in medical decision-making also changed: $50 \%$ to $78 \%$, depending on the type of decision (general, treatment, transfer or ELD), changed their preference towards wanting more or less participation. Pain seemed to be a trigger for patients wanting more involvement, which contrasts with studies suggesting that patients who are more ill tend to give up more control.

Conclusions: Doctors should regularly ask their advanced lung cancer patients how much information and participation they want, because preferences do change in unexpected ways.

Key words: Non-Small-Cell Lung; Patient participation; Medical decision-making; Information preferences; Palliative care; End-of-life decisions 


\section{Introduction}

There is a broad consensus that in physician-patient communication, for both ethical and clinical reasons, providing information to patients about their disease and treatment options and involving them in medical decision-making are important tasks [1-4]. However, especially in a serious illness with limited life expectancy such as advanced cancer, some patients may be reluctant to be fully informed or involved [5, 6]. Therefore, various authors have suggested that physicians have to be flexible and adjust their communication and decisionmaking behavior to the specific preferences of the individual patient $[7,8]$.

There are several studies on the preferences of cancer patients for information and for participation in medicaldecision-making [9-13]. However, these are mostly cross-sectional and little is known about whether and in what direction the preferences of cancer patients change over time throughout the illness trajectory nor about the mechanisms of such changes. Insight into change of preferences over time could help physicians to adjust their communication, optimize the patient-physician relationship and possibly promote patient well-being.

One study compared the information and participation preferences of cancer patients before and after a consultation with the physician and before a second consultation [14]. It was found that general preferences were stable in the short term, while in the long term they were not. Situational factors were important: patients who attended for a routine follow up were more likely to move towards preferring more involvement in decisionmaking than were those whose condition had worsened.

The aim of this study was to examine changes over time in information and participation preferences in advanced lung cancer patients. Information preferences were examined with regard to diagnosis, chances of cure, life expectancy, palliative care and end-of-life decisions with a possible or certain life-shortening effect (ELDs). In Belgium, palliative care is defined and organized in line with the definition of palliative care of the World Health Organization (WHO) [15]. This definition states that "palliative care is an approach that improves the quality of life of patients and their families facing the problem associated with life-threatening illness, through the prevention and relief of suffering" [16]. The WHO also stresses that palliative care is applicable early in the course of the illness in conjunction with other therapies. With the term ELDs, we refer to a specific group of end-of-life decisions that regularly have been studied in Belgium and other European countries and have a 
possible or certain life-shortening effect $[17,18]$. These ELDs are categorized in: withholding or withdrawing life-sustaining treatments, intensified alleviation of symptoms with a possible life-shortening effect, and administration of lethal drugs with the explicit intention of shortening a patient's life (euthanasia, physician assisted suicide or ending life without the patient's explicit request). With regard to the participation preferences we examined medical decisions in general, treatment decisions, health-care-setting transfer decisions and ELDs as well. Lung cancer patients were studied because of the high incidence of this disease and the lack of studies on information and participation preferences in this population [19, 20].

The research questions of this study were:

1: Do preferences of advanced lung cancer patients concerning information and participation in medical decision-making change over time?

2: What are the characteristics of patients with stable versus evolving preferences? 


\section{Methods}

Pulmonologists and oncologists of 3 university and 10 general hospitals in Flanders, Belgium, recruited consecutive patients with stage IIIb or IV non-small-cell lung cancer over one year. Patients had to be Dutchspeaking and physically and psychologically able to participate in the study. Trained interviewers (psychologists, nurses...) interviewed the patients every two months until the fourth and every four months until the sixth interview.

The recruitment period lasted from February 2007 to February 2008 (12 months), and the last interview took place in May 2009.

\section{Measures}

The patient interview consisted of several question lists and scales. Information preferences were assessed via seven items, first information preference in general and further with regard to six specific medical information topics: diagnosis, chances of cure, life expectancy, treatment options, palliative care and end-of-life decisions with a possible or certain life-shortening effect (ELDs). Palliative care was defined broadly to the patients as 'comfort care, for patients who cannot be cured', in correspondence with the WHO definition of palliative care. ELDs were defined as 'non-resuscitation orders, options to accelerate the end of life, and options to forgo or withdraw life-prolonging treatments'. The preferences were presented in the form of statements which patients had to rate on a 6-point Likert scale (from totally disagree to totally agree).The question lists were based on existing questionnaires for cancer patients with confirmed validity, reliability, responsiveness and burden, and on data from qualitative research into terminally ill patients [21, 22].

Participation preferences were measured using an adaptation of the Control Preference Scale, which is frequently used in cancer studies $[12,23]$. Patients were asked the question "Who do you want to take such decisions?" and had to choose one of five possible responses: 1) the doctor on the basis of his/her knowledge, 2) the doctor, but strongly taking my opinion into account, 3) myself and the doctor together on an equal basis, 4) myself, but strongly taking the doctor's opinion into account and 5) myself, on the basis of the information I have or receive. The first two statements denote a preference for primary doctor control over decision-making: doctor control without (1) and with patient input (2). The third statement (3) represents a preference for shared control with the physician and the last two 
statements a preference for primary patient control: patient control with (4) and without (5) doctor input. Patients were given the adapted Control Preference Scale in relation to four situations: 1) medical decisions in general, 2) treatment decisions, 3) transfer decisions, i.e. decisions concerning transfers between health-care-settings (home, hospital, nursing home, ,...) and 4) ELDs. We asked patients to consider decision situations that had actually taken place in the two months before the interview.

To measure quality of life, the EORTC QLQ-C15-PAL was used [24, 25]. The EORTC QLQ-C15-PAL consists of 15 items and incorporates 4 multi-item and 6 single item-scales that measure different aspects of quality of life . The multi-item scales measure physical functioning, emotional functioning, fatigue and pain. The single item-scales measure additional symptoms and global quality of life. Socio-demographic and clinical patient characteristics were recorded by the physician at inclusion of the patient in the study. The clinical characteristic of co-morbidity was measured with the Charlson Index [26]. In Charlson's Co-morbidity Index, the physician has to mark the concomitant diseases the patient suffer from according to a list of 19 diseases that all bear a relative risk of death larger than 1.2. If no disease is marked, a score of 0 is given. Higher scores mean that the patient suffers from one or more concomitant diseases.

Ethics

The protocol of the study was approved by the Ethical Review Board of the University Hospital of the Vrije Universiteit Brussel and of all participating hospitals.

Statistical analysis

Firstly, we explored changes in the average score (population level) on the information and participation preference-items over the interview moments. We used the explorative LOWESS regression technique with the ratings on the preference items as dependent variable, and time (in days since inclusion) as independent variable [27]. The LOWESS technique was chosen because it allows use of all data collected, despite the variable number of interviews per patient (ranging from 1 to 6 interviews). A disadvantage of the technique is that it is only explorative and does not allow for statistical significance statements. 
Secondly, even if there are no changes in the average ratings over time (i.e. no temporal change at the population level), individual patients might still change towards wanting more or less information and participation over time (temporal change at the individual level). To examine these changes and the predictors of these changes indepth, we selected the patients who had been interviewed three times and gave the percentages of patients who changed their preference at the second and/or third interview, compared with the first. For this purpose, the information preference items were dichotomized into wanting versus not wanting information and the participation preference items were categorized into wanting doctor, shared or patient control.

The predictors of change and no change in preferences were explored by testing patient characteristics for significant association with change/no change (from wanting to not wanting information and vice versa, and between wanting doctor, shared or patient control over decision-making), using the Mann Whitney $U$ test and the Fisher's Exact Test. 


\section{Results}

One hundred and ninety six patients were reported to meet the inclusion criteria, of which 152 were included. Of the included patients, 19 could not be enrolled because they were too ill or had died before the first interview, three could not be contacted, and two interviews had too many missing values. In total, 128 patients were interviewed at least once ( $68 \%$ participation rate). Sixty seven of the 128 patients were interviewed three times.

Figure 1 shows the number of participants and those lost to follow-up over the course of the study. The median duration of follow-up was 15 months, counting from the first interview (mean of 14.8 months) as well as from inclusion (mean of 15.2 months).

Patient characteristics (Table 1)

The mean age of the 128 participants was 64 years (range $41-86$ ), $80 \%$ were male and $77 \%$ had a partner. At inclusion, $71 \%$ were being treated with life-prolonging intent, $21 \%$ with palliative intent and $7 \%$ with curative intent. Eighty-two per cent were receiving chemotherapy, sometimes in combination with radiotherapy. Eighty seven percent had a good performance status at inclusion and half were suffering from co-morbidity according to the Charlson Index. The mean estimated life expectancy since inclusion in the study was 10.6 months. There were no significant differences between the inclusion sample and the 67 patients who completed three interviews.

Changes in information and participation preferences of the 'average advanced lung cancer patient' over six interviews

At the population level, advanced lung cancer patients' preferences for information in general (without specifying the topic), and for information about diagnosis, prognosis and treatment options were high shortly after inclusion and remained so over time, until 15 months after inclusion. The preferences for information about palliative care and end-of-life decisions with a possible or certain life-shortening effect (ELDs) were lower, but also did not change over time (Figure 2). 
The preferences for participation in medical decision-making hardly changed over time until approximately one year after inclusion, at which time preferences for participation in all medical decisions (general, treatment, transfer and end-of life decisions) began to increase gradually (Figure 3).

Changes in preferences of individual patients over three interviews $(\mathrm{N}=67)$

\section{Information preferences}

Practically all patients wanted information in general (98\%), about diagnosis (100\%), treatment options (100\%), chances of cure (98\%) and life expectancy (92\%) at t1, shortly after diagnosis of NSCLC IIIb or IV. Almost all still wanted this information at $\mathrm{t} 2$ and $\mathrm{t} 3$, two and four months later, $97 \%$ with regard to information in general, $100 \%$ with regard to diagnosis, $92 \%$ with regard to treatment options, $97 \%$ with regard to chances of cure and $90 \%$ with regard to life expectancy.

As for the topics of palliative care and ELDs, respectively $64 \%$ and $52 \%$ wanted this information at $\mathrm{t} 1$, and $36 \%$ and $48 \%$ did not. Of the patients who did not want this information at $\mathrm{t} 1$, one fourth changed their minds towards wanting it at $\mathrm{t} 2$ or $\mathrm{t} 3(26 \%$ and $23 \%)$ and a very few fluctuated (not wanting - wanting - not wanting information, $0 \%$ and $6 \%$ ). Of the patients who wanted this information at $\mathrm{t} 1,39 \%$ and $26 \%$ respectively changed towards not wanting it and some patients fluctuated (15\% and 18\%).

\section{Participation preferences (Table 2)}

For general medical decisions and treatment and transfer decisions, most patients (51\% to 62\%), wanted doctor control at $\mathrm{t} 1$ rather than shared or personal control; for ELDs most preferred personal control (49\%) rather than shared (39\%) or doctor control (12\%). All preferences, whether for doctor control, shared control or patient control, in all studied medical decisions, were unstable, with half or more patients changing their preference towards wanting more or less control at $\mathrm{t} 2$ or $\mathrm{t} 3$. There was one exception: most patients (76\%) who wanted doctor control in treatment decisions at $\mathrm{t} 1$ had not changed this preference at $\mathrm{t} 2$ or $\mathrm{t} 3$. Overall, $50 \%$ of patients changed their participation preference in treatment decisions at $\mathrm{t} 2$ or $\mathrm{t} 3$ compared with $\mathrm{t} 1 ; 59 \%$ did this for ELDs, $62 \%$ for medical decisions in general and $77 \%$ for transfer decisions. 
Characteristics associated with changes in preferences (Table 3)

Compared with older patients and those with a partner, younger patients and those without a partner were more likely to change their preference for information about palliative care over time from not wanting to wanting information. Religion was also related to change in preferences: non-religious patients were more likely to state they no longer wanted information about palliative care, and to want more participation (i.e. to change from doctor to shared or patient control) in treatment decisions.

A clinical patient characteristic that played an important role in changing preferences was the physical condition of the patient: those with a worse physical condition were more likely to continue over time to want information about palliative care and ELDs, and those with more pain were inclined to want more participation over time in decision-making, at least for medical decisions in general and for transfer decisions. A less than good performance status at inclusion was also related to wanting more participation over time in medical decisions in general.

We checked whether those who changed from wanting to not wanting information about palliative care and ELDs did so because the information had been provided by the physician in the meantime. We found that of these patients only $12 \%$ (palliative care) and $11 \%$ (ELDs) reported having been informed during the interview period. For comparison, of those who consistently wanted information, 53\% and $47 \%$ had received it, and of those who consistently did not want it, $13 \%$ and $4 \%$ had. 


\section{Discussion}

This is the first longitudinal study of information and participation preferences in a cohort of newly diagnosed advanced cancer patients. Information preferences could be measured with regard to diagnosis, chances of cure, life expectancy, palliative care and end-of-life decisions with a possible or certain life-shortening effect (ELDs). Participation preferences could be measured with regard to medical decisions in general, treatment decisions, transfer decisions and end-of-life decisions.

Although the patients as a group did not change much over time towards wanting more or less information or participation, individual patients did. The preferences for information about diagnosis, prognosis and treatment options were stable: almost all patients wanted this information shortly after diagnosis and continued to want it two and four months later. In contrast, the preferences for information about palliative care and ELDs were unstable: of the patients who did not want this information at the onset, one fourth changed towards wanting it after four months, and of those who did want it, 39\% (palliative care) and one fourth (ELDs) changed towards not wanting it. Patients in a worse physical condition were more likely to continue to want information about these topics. The preferences for participation in medical decision-making were also unstable: $50 \%$ to $78 \%$, depending on the type of decision (general, treatment, transfer or end-of-life), changed their preference towards wanting more or less participation over four months. Patients who had more pain were more likely to change towards wanting more participation, at least in medical decisions in general and in transfer decisions.

Strengths of the study were the attempt to have a representative sample of patients by recruiting a cohort of consecutive patients during one year in 13 hospitals, the limited drop-out throughout the study period due to reasons other than death or being too ill (although the latter reason may have concealed loss of interest in the study), and the measurement of aspects of quality of life (physical and emotional functioning, pain and fatigue) along with the preferences of the patients as possible predictors of the preferences.

A limitation of the study was that we only studied the 67 patients that we interviewed three times and not all 128 included patients, and therefore caution is needed in generalizing the findings: most patients who dropped-out before the third interview were too ill or had died. Another limitation was that we explored the association between change in preferences and several patient characteristics, enhancing the likelihood of finding 
associations that are not existent on a population level. A final limitation concerned the possible varying interpretations by the patients of the precise content of the information topics despite of specific definitions.

An important finding of the study was that almost all advanced lung cancer patients wanted and kept on wanting information about diagnosis, treatment options, chances of cure and life expectancy. So, even in those patients who received information about these topics, the preference for information persisted, suggesting that physicians would do well to update their patients regularly. This is in conformity with other study findings showing that advanced cancer patients want information provision to be an ongoing process where the physician continually checks their understanding and goals, particularly as the situation may change during the course of the illness [28].

In contrast, the preferences for information about palliative care and ELDs were more variable and unstable. Of the substantial minority of patients who initially did not want this information, one fourth later did. Of the majority who originally did want it, about half changed their minds - sometimes temporarily - to not wanting it. Thus, it seems that even after a longer period of time (four months after diagnosis), there remain many patients who are not open to information about palliative and end-of-life care. This might compromise their preparedness when they eventually reach the terminal phase and thus might affect the quality of their end-of-life care.

Two comments have to be made. Firstly, it could be that patients change from wanting to not wanting information about palliative care and ELDs because they receive the information in the meantime. However, this explanation is inadequate: only a fraction (one tenth) did actually receive information between interviews. Rather, we observed that a patient's physical condition played a role: patients whose pain level and level of physical functioning were worse kept on wanting information about palliative care, while patients with better functioning and less pain did not. It seems that pain and a lower level of physical functioning worsens quality of life and leads patients to want to be more in control in the hope of achieving more pain and symptom control. The relationship between the physical condition and information preferences also suggests that patients who change towards not wanting information might want information again later on, when their condition worsens. This carries the risk however that, for those who deteriorate rapidly, there will not be time to become sufficiently informed and prepared with regard to palliative and end-of-life care. The fact that so few physicians gave information regarding palliative care and ELDs during the first few months is possibly also important in this 
context as it could lead a patient to think that the issues are not relevant precisely because the physician has not raised them. Secondly, those patients who never wanted information about palliative care were more likely to be older and to have a partner. It might be that some of them rely more on their family or partner, in which case the physician might want to consider addressing family members or partners about palliative care and end of life issues in order to ensure good quality care according to the patient's preferences [29].

Half of patients changed their preference regarding participation in treatment decisions over the first four months of the disease, around $60 \%$ for medical decisions in general and for end-of-life decisions and $77 \%$ for transfer decisions. These relatively high percentages make it necessary for the physician to check a patient's preferences every time a decision is to be made.

Of interest is that patients who - over the first four months of their disease - had more pain were more likely to change over time from doctor control towards shared or patient control, at least in medical decisions in general and in transfer decisions. Pain seems to be a trigger for patients to want more involvement, which somewhat contrasts with studies suggesting that patients who are more ill tend to give up more control $[14,30]$.

To conclude, several recommendations can be made for clinical practice. Firstly, this study corroborates findings of other studies that physicians generally provide information about palliative care and ELDs far less often than patients want it. This speaks to the importance of physician addressing these topics. Secondly, the preferences of advanced lung cancer patients for information about palliative care and ELDs and for participation in medical decision-making are relatively unstable over time. This means that in order to take preferences into account in daily clinical practice, their immediate preferences need to be considered. In this context it is important that physicians talk to their patients about their preferences for information and participation in decision-making and inform them that change in preferences over time is possible and always can be communicated. 


\section{Acknowledgements}

We thank Christine Pauwels-Delanghe, Eva Michiels MD, Jane Ruthven and all the patients, caregivers and interviewers who have contributed to this work.

\section{Conflict of Interest Statement}

The authors have declared no conflicts of interest.

\section{Role of funding}

This work was supported by the Fund for Scientific Research in Flanders, Belgium [grant number FWO/AL336]; the Research Council of the Vrije Universiteit Brussel [grant number HOA2 and OZR1218]; and the AstraZeneca Foundation. The sponsors had no role in study design, collection, analysis and interpretation of data, in the writing of the report or in the decision to submit the paper for publication. 


\section{References}

1. American College of Physicians Ethics Manual. Third edition (1992) Ann Intern Med 117: 947-960

2. Emanuel EJ, Emanuel LL (1992) Four models of the physician-patient relationship. JAMA 267: 22212226

3. Arora NK (2003) Interacting with cancer patients: the significance of physicians' communication behavior. Soc Sci Med 57: 791-806

4. Dias L, Chabner BA, Lynch TJ, Jr., Penson RT (2003) Breaking bad news: a patient's perspective. Oncologist: 8: 587-596

5. de Haes H, Koedoot N (2003) Patient centered decision making in palliative cancer treatment: a world of paradoxes. Patient Educ Couns 50: 43-49

6. Deschepper R, Bernheim JL, Vander Stichele R, Van den Block L, Michiels E, Van Der Kelen G, Mortier F, Deliens L (2008) Truth-telling at the end of life: a pilot study on the perspective of patients and professional caregivers. Patient Educ Couns 71: 52-56

7. de Haes H (2006) Dilemmas in patient centeredness and shared decision making: a case for vulnerability. Patient Educ Couns 62: 291-298

8. Bernheim J (2001) The doctor's dilemma between patient autonomy and physician beneficence at the end of life II. A patient - physician information and covenant (ICC) as a procedural-ethical solution. (In Dutch). Ethiek en Maatschappij 4: 114-121

9. Jenkins V, Fallowfield L, Saul J (2001) Information needs of patients with cancer: results from a large study in UK cancer centres. Br J Cancer 84: 48-51

10. Gaston CM, Mitchell G (2005) Information giving and decision-making in patients with advanced cancer: a systematic review. Soc Sci Med 61: 2252-2264

11. Davidson JR, Brundage MD, Feldman-Stewart D (1999) Lung cancer treatment decisions: patients' desires for participation and information. Psychooncology 8: 511-520 
12. Gattellari M, Butow PN, Tattersall MH (2001) Sharing decisions in cancer care. Soc Sci Med 52: 18651878

13. Curtis JR, Engelberg R, Young JP, Vig LK, Reinke LF, Wenrich MD, McGrath B, McCown E, Back AL (2008) An approach to understanding the interaction of hope and desire for explicit prognostic information among individuals with severe chronic obstructive pulmonary disease or advanced cancer. J Palliat Med 11: 610-620

14. Butow PN, Maclean M, Dunn SM, Tattersall MH, Boyer MJ (1997) The dynamics of change: cancer patients' preferences for information, involvement and support. Ann Oncol 8: 857-863

15. Wet betreffende palliatieve zorg 14 juni 2002. Belgisch Staatsblad 26 oktober 2002. [Law concerning palliative care June 14, 2002. Belgian official collection of the Laws October 26, 2002] (in Dutch)

16. National cancer control programmes: policies and managerial guidelines (2002) Geneva: World Health Organisation

17. Bilsen J, Cohen J, Chambaere K, Pousset G, Onwuteaka-Philipsen BD, Mortier F, Deliens L (2009) Medical end-of-life practices under the euthanasia law in Belgium. N Engl J Med 361: 1119-1121

18. van der Heide A, Deliens L, Faisst K, Nilstun T, Norup M, Paci E, Van Der WG, van der Maas PJ (2003) End-of-life decision-making in six European countries: descriptive study. Lancet 362: 345-350

19. Bonomi P, Kim K, Fairclough D, Cella D, Kugler J, Rowinsky E, Jiroutek M, Johnson D (2000) Comparison of survival and quality of life in advanced non-small-cell lung cancer patients treated with two dose levels of paclitaxel combined with cisplatin versus etoposide with cisplatin: results of an Eastern Cooperative Oncology Group trial. J Clin Oncol 18: 623-631

20. Herbst RS, Giaccone G, Schiller JH, Natale RB, Miller V, Manegold C, Scagliotti G, Rosell R, Oliff I, Reeves JA, Wolf MK, Krebs AD, Averbuch SD, Ochs JS, Grous J, Fandi A, Johnson DH (2004) Gefitinib in combination with paclitaxel and carboplatin in advanced non-small-cell lung cancer: a phase III trial--INTACT 2. J Clin Oncol 22: 785-794

21. Wen KY, Gustafson DH (2004) Needs assessment for cancer patients and their families. Health Qual Life Outcomes 2: 11 
22. Kutner JS, Steiner JF, Corbett KK, Jahnigen DW, Barton PL (1999) Information needs in terminal illness. Soc Sci Med 48: 1341-1352

23. Degner LF, Sloan JA, Venkatesh P (1997) The Control Preferences Scale. Can J Nurs Res 29: 21-43

24. Groenvold M, Petersen MA, Aaronson NK, Arraras JI, Blazeby JM, Bottomley A, Fayers PM, de GA, Hammerlid E, Kaasa S, Sprangers MA, Bjorner JB (2006) The development of the EORTC QLQ-C15PAL: a shortened questionnaire for cancer patients in palliative care. Eur J Cancer 42: 55-64

25. Aaronson NK, Ahmedzai S, Bergman B, Bullinger M, Cull A, Duez NJ, Filiberti A, Flechtner H, Fleishman SB, de Haes JC, et al (1993) The European Organization for Research and Treatment of Cancer QLQ-C30: a quality-of-life instrument for use in international clinical trials in oncology. J Natl Cancer Inst 85: 365-376

26. Charlson ME, Pompei P, Ales KL, MacKenzie CR (1987) A new method of classifying prognostic comorbidity in longitudinal studies: development and validation. J Chronic Dis 40: 373-383

27. Cleveland WS, Devlin SJ (1988) Locally-Weighted Regression: An Approach to Regression Analysis by Local Fitting. Journal of the American Statistical Association 83: 596-610

28. Parker SM, Clayton JM, Hancock K, Walder S, Butow PN, Carrick S, Currow D, Ghersi D, Glare P, Hagerty R, Tattersall MH (2007) A systematic review of prognostic/end-of-life communication with adults in the advanced stages of a life-limiting illness: patient/caregiver preferences for the content, style, and timing of information. J Pain Symptom Manage 34: 81-93

29. Street RL, Gordon HS (2008) Companion participation in cancer consultations. Psychooncology 17: 244251

30. Degner LF, Sloan JA (1992) Decision making during serious illness: what role do patients really want to play? J Clin Epidemiol 45: 941-950 


\section{FIGURES}

Figure 1 Participation of NSCLC IIIb or IV patients in study (N=128)

Figure 2 Information preferences of the studied patients over time (Lowess curve)

Figure 3 Participation preferences of the studied patients over time (Lowess curve) 


\begin{tabular}{|c|c|c|c|c|}
\hline & & $\begin{array}{l}\text { All patients } \\
\qquad N=128\end{array}$ & $\begin{array}{c}\text { Patients with } 3 \\
\text { consecutive } \\
\text { interviews } \\
N=67\end{array}$ & P-value* \\
\hline & & Mean (SD) & Mean (SD) & \\
\hline \multicolumn{2}{|l|}{ Age } & $64.4(9.7)$ & $64.2(9.8)$ & 0.884 \\
\hline & & $\mathbf{N}(\%)$ & $\mathrm{N}(\%)$ & \\
\hline \multirow[t]{2}{*}{ Sex } & Male & $102(79.7)$ & $53(79.1)$ & \multirow[t]{2}{*}{1.000} \\
\hline & Female & $26(20.3)$ & $14(20.9)$ & \\
\hline \multirow{2}{*}{ Partner } & Yes & $98(76.6)$ & $53(79.1)$ & \multirow{2}{*}{0.722} \\
\hline & No & $30(23.4)$ & $14(20.9)$ & \\
\hline \multirow[t]{2}{*}{ Living situation } & Home alone & $31(24.2)$ & $17(25.4)$ & \multirow[t]{2}{*}{0.863} \\
\hline & Home with others & $97(75.8)$ & $50(74.6)$ & \\
\hline \multirow[t]{4}{*}{ Education } & Primary school & $24(18.8)$ & $12(17.9)$ & \multirow[t]{4}{*}{0.699} \\
\hline & Lower secondary & $42(32.8)$ & $17(25.4)$ & \\
\hline & Higher secondary & $40(31.2)$ & $25(37.3)$ & \\
\hline & Higher education & $22(17.2)$ & $13(19.4)$ & \\
\hline \multirow[t]{2}{*}{ Religion } & Religious & $93(72.7)$ & $49(71.0)$ & \multirow[t]{2}{*}{1.000} \\
\hline & Not religious & $35(27.3)$ & $18(26.1)$ & \\
\hline \multirow[t]{2}{*}{ Treating hospital } & University & $59(46.1)$ & $29(43.3)$ & \multirow[t]{2}{*}{0.763} \\
\hline & General & $69(53.9)$ & $38(56.7)$ & \\
\hline \multirow[t]{4}{*}{ Treatment aim } & Cure & $9(7.0)$ & $7(10.4)$ & \multirow[t]{4}{*}{0.805} \\
\hline & Life prolongation & $91(71.1)$ & $47(70.1)$ & \\
\hline & Palliation & $27(21.1)$ & $13(19.4)$ & \\
\hline & Other (no treatment) & $1(0.8)$ & $0(0.0)$ & \\
\hline \multirow[t]{2}{*}{ Chemotherapy } & Yes & $105(82.0)$ & $53(79.1)$ & \multirow[t]{2}{*}{0.701} \\
\hline & No & $23(18.0)$ & $14(20.9)$ & \\
\hline \multirow[t]{2}{*}{ Radiotherapy } & Yes & $41(32.0)$ & $23(34.3)$ & \multirow[t]{2}{*}{0.751} \\
\hline & No & $87(68.0)$ & $44(65.7)$ & \\
\hline \multirow[t]{4}{*}{ Contact with $\mathrm{GP}^{\mathrm{a}}$} & Once a week or more & $11(8.6)$ & $3(4.5)$ & \multirow[t]{4}{*}{0.737} \\
\hline & Once every 2 weeks & $17(13.3)$ & $6(9.0)$ & \\
\hline & Once every month & $59(46.1)$ & $33(49.3)$ & \\
\hline & Less & $41(32.0)$ & $25(37.3)$ & \\
\hline \multirow[t]{3}{*}{ Co-morbidity ${ }^{b}$} & 0 & $65(50.8)$ & $32(47.8)$ & \multirow[t]{3}{*}{0.897} \\
\hline & $1-2$ & $53(41.4)$ & $29(43.3)$ & \\
\hline & $3-4$ & $10(7.8)$ & $6(9.0)$ & \\
\hline \multirow[t]{5}{*}{ Performance status $^{c}$} & 0 & $31(24.2)$ & $22(32.8)$ & \multirow[t]{5}{*}{0.313} \\
\hline & 1 & $81(63.3)$ & $42(62.7)$ & \\
\hline & 2 & $11(8.6)$ & $2(3.0)$ & \\
\hline & 3 & $3(2.3)$ & $0(0.0)$ & \\
\hline & 4 & $2(1.6)$ & $1(1.5)$ & \\
\hline & Mean (SD) & Mean (SD) & \\
\hline Life expectancy (in I & & $10.6(4.5)$ & $11.8(4.6)$ & 0.083 \\
\hline $\begin{array}{l}{ }^{*} \text { P-value of signific } \\
\text { a } \text { Three patients (in } n \\
\text { in the category 'Less } \\
\text { b Co-morbidity score } \\
{ }^{c} \text { Performance status } \\
\text { to } 4=\text { completely dis } \\
{ }^{d} \text { Estimated by treati } \\
\text { * Significance testing }\end{array}$ & $\begin{array}{l}\text { In using Man-Whitney } \\
\text { two patients (in } n=67 \text { ) } \\
\text { to ECOG: Eastern Co } \\
\text { an. } \\
\text { nn-Whitney U or Fisher }\end{array}$ & $\begin{array}{l}\text { Fisher's Exact } \\
\text { ted that they d } \\
\text { ive Oncology } \\
\text { act test. }\end{array}$ & $\begin{array}{l}\text { ave a GP. They we } \\
\text { ranging from } 0=\end{array}$ & $\begin{array}{l}\text { included } \\
\text { ly active }\end{array}$ \\
\hline
\end{tabular}




\begin{tabular}{|c|c|c|c|c|}
\hline & \multicolumn{4}{|c|}{$\begin{array}{l}N(\%) \text { of patients who changed and didn't change their participation preference at } \\
t 2 \text { and } t 3 \text {, compared to } 11\end{array}$} \\
\hline & $\begin{array}{c}\text { Medical decisions } \\
\text { in general }\end{array}$ & $\begin{array}{c}\text { Treatment } \\
\text { decisions }\end{array}$ & Transfer decisions & $\begin{array}{c}\text { End-of-life } \\
\text { decisions }\end{array}$ \\
\hline Of patients who wanted doctor control at t1 & $N=34(100)$ & $N=41(100)$ & $N=37(100)$ & $N=7(100)$ \\
\hline No change at $\mathrm{t} 2$ and $\mathrm{t} 3$ & $17(50.0)$ & $31(75.6)$ & $11(29.7)$ & $2(28.6)$ \\
\hline Evolution towards wanting shared or patient control & $14(41.2)$ & $8(19.5)$ & $20(54.1)$ & $4(57.1)$ \\
\hline Fluctuation: doctor control/ ... /doctor control & $3(8.8)$ & $2(4.9)$ & $6(16.2)$ & $1(14.3)$ \\
\hline Of patients who wanted shared control at t1 & $N=25(100)$ & $N=15(100)$ & $N=16(100)$ & $N=23(100)$ \\
\hline No change at $\mathrm{t} 2$ and $\mathrm{t} 3$ & $8(32.0)$ & $1(6.7)$ & $1(6.3)$ & $7(30.4)$ \\
\hline Evolution towards wanting patient or doctor control & $12(48.0)$ & $8(53.3)$ & $11(68.7)$ & $9(39.1)$ \\
\hline - Patient control & $3(12.0)$ & $0(0.0)$ & $4(25.0)$ & $5(21.7)$ \\
\hline - Doctor control & $9(36.0)$ & $8(53.3)$ & $7(43.7)$ & $4(17.4)$ \\
\hline $\begin{array}{l}\text { Fluctuation: shared control/.../shared control; } \\
\text { shared/doctor/ patient and shared/patient/doctor }\end{array}$ & $5(20.0)$ & $6(40.0)$ & $4(25.0)$ & $7(30.4)$ \\
\hline Of patients who wanted personal control at t1 & $N=7(100)$ & $N=10(100)$ & $N=13(100)$ & $N=29(100)$ \\
\hline No change at $\mathrm{t} 2$ and $\mathrm{t} 3$ & $0(0.0)$ & $1(10.0)$ & $3(23.1)$ & $15(51.7)$ \\
\hline Evolution towards wanting shared or doctor control & $6(85.7)$ & $6(60.0)$ & $5(38.5)$ & $10(34.5)$ \\
\hline Fluctuation: patient control/.../patient control & $1(14.3)$ & $3(30.0)$ & $5(38.5)$ & $4(13.7)$ \\
\hline Of all patients (Total) & $N=66(100)$ & $N=66(100)$ & $N=66(100)$ & $N=59(100)$ \\
\hline No change at $\mathrm{t} 2$ and $\mathrm{t} 3$ & $25(37.9)$ & $33(50.0)$ & $15(22.7)$ & $24(40.7)$ \\
\hline Evolution & $32(48.5)$ & $22(33.3)$ & $36(54.5)$ & $23(39.0)$ \\
\hline Fluctuation & $9(13.6)$ & $11(16.7)$ & $15(22.7)$ & $12(20.3)$ \\
\hline
\end{tabular}


Table 3 Characteristics of patients who changed and did not change their preferences for information about palliative care and ELDs and for participation in medical decision-making

\begin{tabular}{|c|c|c|c|c|}
\hline & \multirow{2}{*}{ Change in preferences over time (at $\mathbf{t} 2$ or $\mathrm{t} 3$ ) } & \multicolumn{2}{|c|}{ Mean or \% of patients } & \multirow[t]{2}{*}{$P^{*}$} \\
\hline & & Change & No change & \\
\hline Age (in years) & Change to wanting information about palliative care & $\begin{array}{r}\text { Mean: } 60.3 \\
(n=6)\end{array}$ & $\begin{array}{r}\text { Mean: } 71.3 \\
(n=17) \\
\end{array}$ & 0.015 \\
\hline $\begin{array}{l}\text { Having no partner } \\
\text { (versus having a partner) }\end{array}$ & Change to wanting information about palliative care & $\begin{array}{r}50.0 \% \\
(n=6)\end{array}$ & $\begin{array}{l}5.9 \% \\
(n=17)\end{array}$ & 0.040 \\
\hline \multirow[t]{2}{*}{$\begin{array}{l}\text { Not religious } \\
\text { (versus religious) }\end{array}$} & Change to not wanting information about palliative care & $\begin{array}{l}87.5 \% \\
\quad(n=16)\end{array}$ & $\begin{array}{l}47.7 \% \\
\quad(n=19)\end{array}$ & 0.030 \\
\hline & Change to wanting more involvement in treatment decisions & $\begin{array}{l}62.5 \% \\
(n=8)\end{array}$ & $\begin{array}{l}19.4 \% \\
(n=31)\end{array}$ & 0.028 \\
\hline \multirow{2}{*}{$\begin{array}{l}\text { Average physical functioning } \\
\text { over } \mathbf{t} 1, \mathbf{t} \mathbf{2} \text { and } \mathbf{t} 3 \\
\text { (high score: healthy level) }\end{array}$} & Change to not wanting information about palliative care & $\begin{array}{r}\text { Mean: } 86.1 \\
(n=16)\end{array}$ & $\begin{array}{r}\text { Mean: } 70.6 \\
(n=19) \\
\end{array}$ & 0.003 \\
\hline & Change to not wanting information about ELDs & $\begin{array}{r}\text { Mean: } 86.8 \\
(n=9)\end{array}$ & $\begin{array}{r}\text { Mean: } 73.5 \\
(n=19) \\
\end{array}$ & 0.019 \\
\hline \multirow[t]{3}{*}{$\begin{array}{l}\text { Average pain over t1, t2, t3 } \\
\text { (low score: healthy level) }\end{array}$} & Change to not wanting information about palliative care & $\begin{array}{r}\text { Mean: } 21.9 \\
(n=16)\end{array}$ & $\begin{array}{r}\text { Mean: } 37.7 \\
(n=19) \\
\end{array}$ & 0.029 \\
\hline & $\begin{array}{l}\text { Change to wanting more involvement in medical decisions in } \\
\text { general }\end{array}$ & $\begin{array}{r}\text { Mean: } 31.7 \\
(n=14)\end{array}$ & $\begin{array}{r}\text { Mean: } 14.4 \\
(n=17) \\
\end{array}$ & 0.040 \\
\hline & Change to wanting more involvement in transfer decisions & $\begin{array}{r}\text { Mean: } 24.4 \\
(n=20)\end{array}$ & $\begin{array}{r}\text { Mean: } 7.1 \\
(n=11)\end{array}$ & 0.021 \\
\hline $\begin{array}{l}\text { Average fatigue over t1, t2, t3 } \\
\text { (low score: healthy level) }\end{array}$ & Change to not wanting information about palliative care & $\begin{array}{r}\text { Mean: } 28.4 \\
(n=16)\end{array}$ & $\begin{array}{r}\text { Mean: } 49.4 \\
(n=19) \\
\end{array}$ & 0.007 \\
\hline $\begin{array}{l}\text { Co-morbidity at inclusion } \\
\text { (versus no Co-morbidity) }^{\mathrm{a}}\end{array}$ & Change to not wanting information about ELDs & $\begin{array}{r}22.2 \% \\
(n=9)\end{array}$ & $\begin{array}{l}68.4 \% \\
(n=19)\end{array}$ & 0.025 \\
\hline $\begin{array}{l}\text { Performance status at inclusion: } \\
\text { active (versus less active) }{ }^{b}\end{array}$ & $\begin{array}{l}\text { Change to wanting more involvement in medical decisions in } \\
\text { general }\end{array}$ & $\begin{array}{r}14.3 \% \\
(n=14)\end{array}$ & $\begin{array}{l}58.8 \% \\
\quad(n=17)\end{array}$ & 0.024 \\
\hline \multicolumn{5}{|c|}{$\begin{array}{l}* P \text {-value of significance testing }(P<0.05) \text { using Man-Whitney } U \text { or Fisher's Exact Test. Patient characteristics that were tested for a significant } \\
\text { association with change and no change in preferences were: } 1) \text { socio-demographic and clinical characteristics measured at inclusion (age, sex, } \\
\text { educational level, having a partner, religion, treatment aim, performance status, comorbidity) and } 2) \text { quality of life variables measured at each } \\
\text { interview averaged over the three interviews (EORTC QLQ-C15-PAL multiple item-scales: physical functioning, emotional functioning, fatigue and } \\
\text { pain). } \\
\text { a Co-morbidity score of } 1-4 \text { (co-morbidity) versus } 0 \text { (no co-morbidity), measured by Charlson Index. }\end{array}$} \\
\hline
\end{tabular}


